\title{
First xiphosuran traceway in the middle Muschelkalk facies (Middle Triassic) of the Catalan Basin (NE Iberian Peninsula)
}

\author{
Chabier DE JAIME-SOGUERO ${ }^{1 *}$, Eudald MUJAL ${ }^{1,2}$ \& Josep FORTUNY ${ }^{1}$
}

${ }^{1}$ Institut Català de Paleontologia Miquel Crusafont, Universitat Autònoma de Barcelona, Edifici ICTA-ICP, c/ Columnes s/n, Campus de la UAB, 08193 Cerdanyola del Vallès, Barcelona, Spain; chabier.dejaime@icp.cat; josep.fortuny@icp.cat

${ }^{2}$ Staatliches Museum für Naturkunde Stuttgart, Rosenstein 1, 70191 Stuttgart, Germany; eudald.mujalgrane@smns-bw.de

*Corresponding author

De Jaime-Soguero, C., Mujal, E. \& Fortuny, J. 2020. First xiphosuran traceway in the middle Muschelkalk facies (Middle Triassic) of the Catalan Basin (NE Iberian Peninsula). [Primer rastro de xifosuro en las facies Muschelkalk medio (Triásico Medio) de la Cuenca Catalana (NE de la Península Ibérica)]. Spanish Journal of Palaeontology, 35 (2), 197-208.

Manuscript received 29 November 2019

Manuscript accepted 13 July 2020 https://doi.org/10.7203/sjp.35.2.18483

(C) Sociedad Española de Paleontología ISSN 2255-0550

\begin{abstract}
In the last decade, the first ichnoassamblages from the middle Muschelkalk facies (upper Anisian-middle Ladinian) of the Catalan Basin (NE Iberian Peninsula) have been discovered. Herein, the first xiphosuran trace fossils are described from the locality of Penya Rubí, a newly discovered ichnosite from the Catalan Basin. The finding opens a window into peri-Tethys ecosystems with coastal influence. The traceway is referred to the ichnogenus Kouphichnium, a locomotion trace attributed to xiphosurans. The traceway preserves telson grooves and different imprint morphologies from the various appendages. The traceway pattern and arrangement of the different traces suggest a crawling locomotion style. The sedimentology suggests a coastal zone with areas influenced by tides (intertidal flat). The morphological variations of the ichnites are correlated to substrate rheology, the locomotion of the tracemaker and environmental conditions.
\end{abstract}

Keywords: Invertebrate ichnology, Kouphichnium, telson, Middle Triassic, coastal palaeoenvironment.

\section{RESUMEN}

En la última década, se han descubierto las primeras icnoasociaciones de las facies del Muschelkalk medio (Anisiense superior-Ladiniense medio) de la Cuenca Catalana (NE de la Península Ibérica). Aquí se describe el primer rastro fósil de xifosuro de la localidad de Penya Rubí, un icnoyacimiento descubierto recientemente en la Cuenca Catalana. El hallazgo abre una ventana dentro de los ecosistemas del peri-Tethys con influencia costera. El rastro ha sido identificado como Kouphichnium, una traza de locomoción asociada a xifosuros fósiles. El rastro preserva surcos del telson e impresiones de los distintos apéndices, que resultan en morfologías diferentes. El patrón del rastro y la disposición de las distintas trazas sugiere un estilo de locomoción de reptación (“crawling”). La sedimentología sugiere una zona costera, con áreas de influencia mareal (intermareal). Las variaciones morfológicas de las icnitas están correlacionadas con la reología del sustrato, la locomoción del productor de las huellas y las condiciones ambientales originales.

Palabras clave: Icnología de invertebrados, Kouphichnium, telson, Triásico Medio, paleoambiente costero. 


\section{INTRODUCTION}

The order Xiphosura Laterille, 1802, generally known as horseshoe crabs, consists of aquatic chelicerate arthropods with a fossil record extending from the Ordovician to the present (Rudkin et al., 2008; Lamsdell, 2016). Although xiphosurans have inhabited in many different environments through most of the Phanerozoic, and the group has survived several mass extinction events, currently only four marine species of the family Limulidae survive (Gaillard, 2011). Since the morphology of the group remained largely unchanged through much of its evolution, the extant species are considered as "living fossils" (Gaillard, 2011; Kin \& Błażejowski, 2014). The xiphosurans show a maximum diversity during the Carboniferous and Triassic periods (Moore et al., 2007). Xiphosuran trace fossils provide additional information about the palaeobiology of these animals and their habitats (Gaillard, 2011; Fernández \& Pazos, 2013; Mujal et al., 2018a; Bicknell et al., 2019; Shibata \& Varricchio, 2020).

The Triassic fossil record of Xiphosura is particularly interesting as it helps to elucidate how this group survived after the end-Permian mass extinction (Błażejowski et al., 2017; Mujal et al., 2018a). Even more important, in general terms, after the end-Permian mass extinction, the diversity of life shows a general diminishment, with a very poor terrestrial record, particularly in central Pangea (Benton \& Newell, 2014). Biodiversity recovery in marine ecosystems was faster than in terrestrial ecosystems due to a high increase of marine productivity after the mass extinction event (Shen et al., 2015).

Considering these concepts, the discovery of a new fossil traceway referred to Xiphosura from the northeastern Iberian Peninsula (western Tethys) is of special interest, because it was recovered from the middle Muschelkalk facies of the Catalan Basin. Triassic facies are diachronic at European level due to the different influence of sea level (i.e., different transgressions and regressions) among the western Tethys basins (Virgili et al., 1977; EscuderoMozo et al., 2015; Franz et al., 2015). In the particular case of the Catalan Basin, a regression episode occurred during the late Anisian-middle Ladinian affected coastal environments, creating numerous coastal river floodplains (Solé de Porta et al., 1987; Calvet \& Marzo, 1994; Ortí et al., 2018). This regression is represented in the sedimentary record as red beds and evaporite deposits between the marine Muschelkalk facies (Calvet \& Marzo, 1994; Ortí et al., 2018).

In the NE Iberian Peninsula, few xiphosuran arthropod remains have been recovered (both direct and indirect evidences). Three taxa from the Muschelkalk facies (Ladinian, upper Middle Triassic) have been described in the Catalan Basin to date (Vía-Boada \& Villata, 1966; Romero \& Vía-Boada, 1977; Vía, 1987). Also, several xiphosuran traceways and body imprints have been described from one locality of the terrestrial lower Buntsandstein Pyrenean Basin dated from the Lower Triassic (upper Olenekian) (Mujal et al., 2018a).

The present study analyses the first record of a xiphosuran traceway from the middle Muschelkalk of the Iberian Peninsula. From this unit of the Catalan Basin different ichnoassociations of tetrapod trace fossils have been reported so far (Mujal et al., 2015, 2018b). Thus, the newly discovered traceway adds relevant data on the palaeodiversity of these ecosystems. The main objective of this study is the ichnotaxonomy of the traceway recovered from the ichnosite of Penya Rubí (Vallirana, Barcelona province). Further, this traceway provides information about the palaeoenvironment and palaeogeography of its tracemaker.

\section{GEOLOGICAL SETTING}

The outcrop of Penya Rubí is located in the Catalan Basin, currently forming the Catalan Coastal Ranges (Fig. 1). The Catalan Basin is situated at the northeast of the Iberian Peninsula and began to develop during the middle to late Permian due to the extension of the Iberian plate (GalánAbellán et al., 2013). The Triassic sedimentary succession of the Catalan Basin is composed of the so-called Germanic facies, recognised at European scale, which comprise the following lithostratigraphic units: Buntsandstein, lower (M1), middle (M2) and upper (M3) Muschelkalk, Keuper and Imón Formation (Calvet \& Marzo, 1994). The Triassic succession presents a thickness of 500-800 meters (Calvet et al., 1990).

During the Middle Triassic the sedimentary environmental conditions changed drastically in different areas of the Iberian massif, but especially affecting the Catalan Basin. Such changes are reflected in the three different Muschelkalk facies successions within the Catalan Coastal Ranges: They represent marine environments (M1 and M3) separated by the coastal and alluvial environments (M2) (Calvet \& Marzo, 1994; Ortí et al., 2018). Following these events, during the Lower Triassic, remains of braided and meandering river settings under arid and semiarid climatic conditions are represented by the Buntsandstein facies (Galán-Abellán et al., 2013; Mujal et al., 2017). During the early Anisian (Middle Triassic) there were abundant fluvial systems that gradually change into coastal and marine settings (lower Muschelkalk facies - M1), but later emerging again during the late Anisianmiddle Ladinian as a result of a short regression episode, as represented by the middle Muschelkalk (M2) facies; afterwards, a major transgression adjusted coastal and marine settings (upper Muschelkalk facies - M3) (Calvet \& Marzo, 1994; Ortí et al., 2018). This is the reason why the 
continental environments dominated in the Catalan Basin (but not in other Iberian basins), and the upper Anisian and lower Ladinian are characterised by the predominance of distal alluvial, coastal and shallow marine successions (Escudero-Mozo et al., 2015; Ortí et al., 2018). Herein, the studied outcrop corresponds to the middle Muschekalk facies, dated as late Anisian-middle Ladinian based on palynological and biostratigraphic analysis (Solé de Porta et al., 1987; Márquez-Aliaga et al., 2000; Mujal et al., 2015, 2018b).

\section{MATERIAL AND METHODS}

An in-situ slab with a xiphosuran traceway was discovered in the Penya Rubí ichnosite (Vallirana, Catalan Basin). The slab was recovered from a reddish sandstone stratum (50-60 cm thick). The slab dimensions are: $50.8 \mathrm{~cm}$ long, $29.45 \mathrm{~cm}$ wide and $4.13 \mathrm{~cm}$ thick. The ichnological study was carried out in the lab. The slab is stored at the Institut Català de Paleontologia Miquel Crusafont (Sabadell, Catalonia, Spain) and labelled as IPS110272.

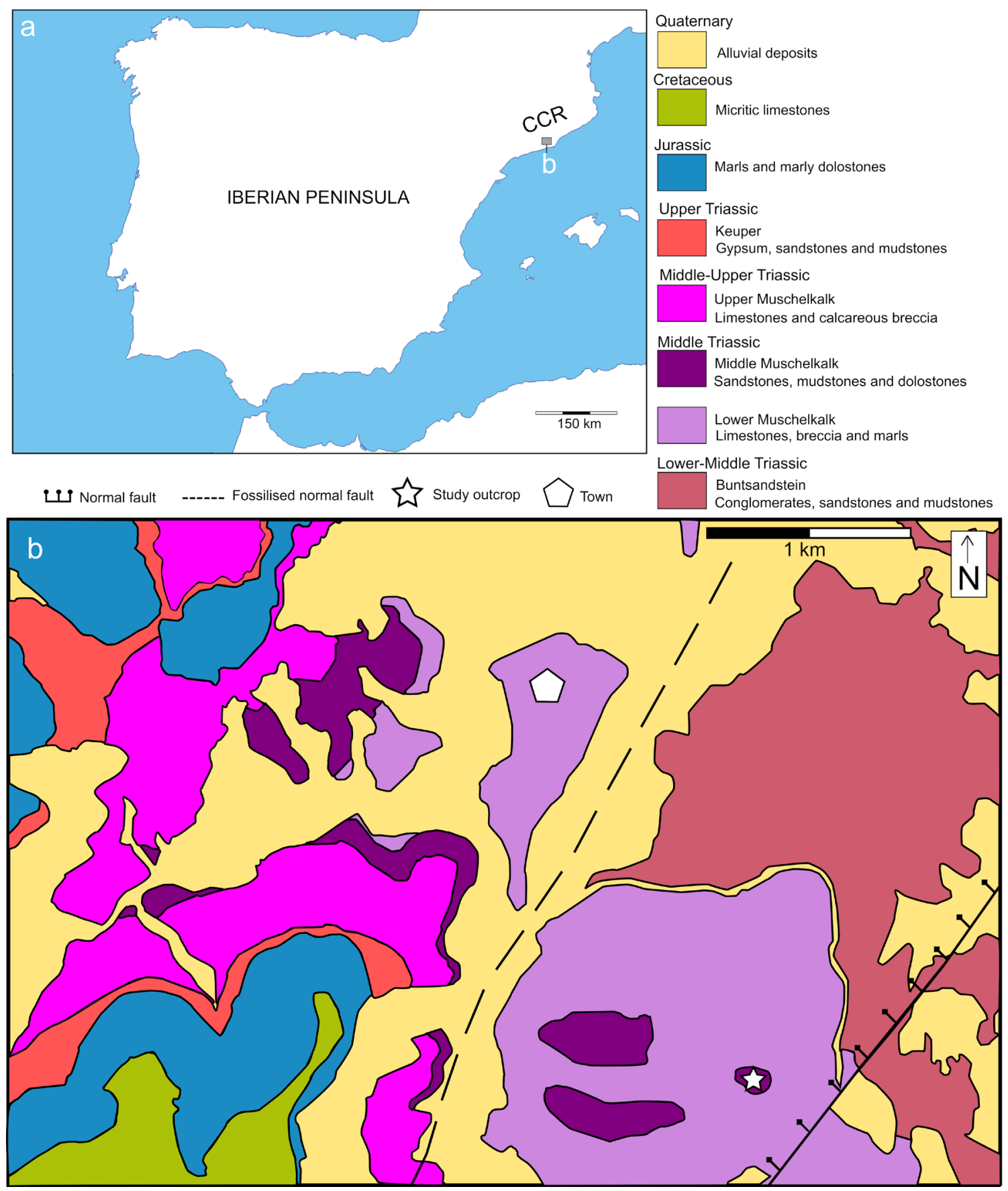

Figure 1. Geographic location and simplified geological maps of studied areas. a) Location of the Catalan Basin in the Iberian Peninsula. b) Geological map of the Triassic around Penya Rubí (Vallirana) in the Catalan Basin. Maps modified from the Institut Cartogràfic i Geològic de Catalunya (ICGC). 
A stratigraphic log was performed using a Jacob staff and meter stick. The slab was located in its exact stratigraphic level. After measuring, the data were translated into a stratigraphic sequence using the software Inkscape (v. 0.92.3).

Once in the lab, the traces were measured by calliper and with digital measuring tools from the image manipulating software GIMP (v. 2.10.0). Also, light was shone from different directions to appreciate all the details of the impressions. The traceway was digitised photogrammetrically. A three-dimensional photogrammetric model of the slab (IPS110272) that contains Kouphichnium isp. is available from MorphoBank http://morphobank.org/permalink/?P3770. This method consists of creating a three-dimensional model using photographs. The photographs were obtained with a digital reflex camera Panasonic Lumix DMC-FZ200 following the procedures of Falkingham (2012) and Mallison \& Wings (2014). The three-dimensional models were processed with three programs, following the procedures of Mujal et al. (2020, see references therein for a review): Agisoft Photoscan (standard version 1.1.4), to generate a dense point cloud, MeshLab (v. 2016.12) to edit the mesh (cleaning, scale and orientation) and ParaView (v. 5.5.0) to generate a coloured depth map and contours. The final three-dimensional meshes were used to complement the morphological study of each trace and their deepness. These meshes, refined and improved following some procedures (Marcé-Nogué et al., 2015), can be also used in biomechanical studies to evaluate tracemaker locomotion.

\section{OUTCROP OF PENYA RUBÍ (VALLIRANA, CATALAN BASIN)}

The Triassic outcrops in the studied area include Buntsandstein, Muschelkalk (M1, M2, M3) and Keuper facies, and the recovered traceway is located in the M2 unit (Figs 2-3). The middle Muschelkalk facies are composed of clays and sandstones interbedded with evaporites (Ramón \& Calvet, 1987; Ortí et al., 2018). The sandstones are fine-grained, with a clayey matrix and limestone cement. Sandstone grains are, in decreasing order, composed of quartz, feldspar and mica. The mudstones are mainly fine detrital sediments and appear alternated with sandstone strata (Calvet \& Marzo, 1994; Ortí et al., 2018).

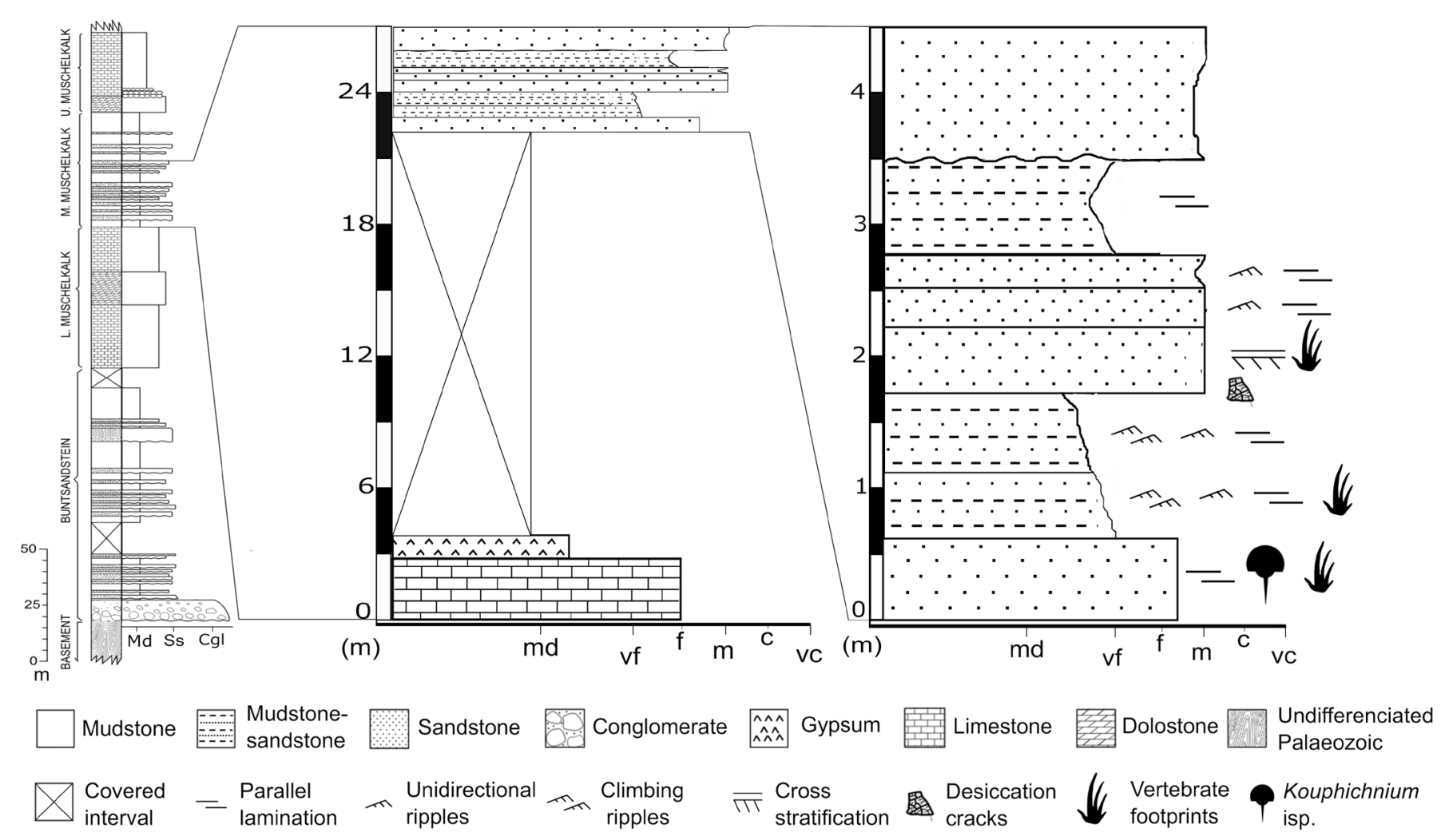

Figure 2. Stratigraphic log of the middle Muschelkalk facies from Penya Rubí (Vallirana, Catalan Basin) where tetrapod footprints and invertebrate traces appear (uppermost part of the outcropping section). Md/md: Mudstone; Ss: Sandstone; vf: very fine; f: fine; m: medium; c: coarse; vc: very coarse; Cgl: Conglomerate. 

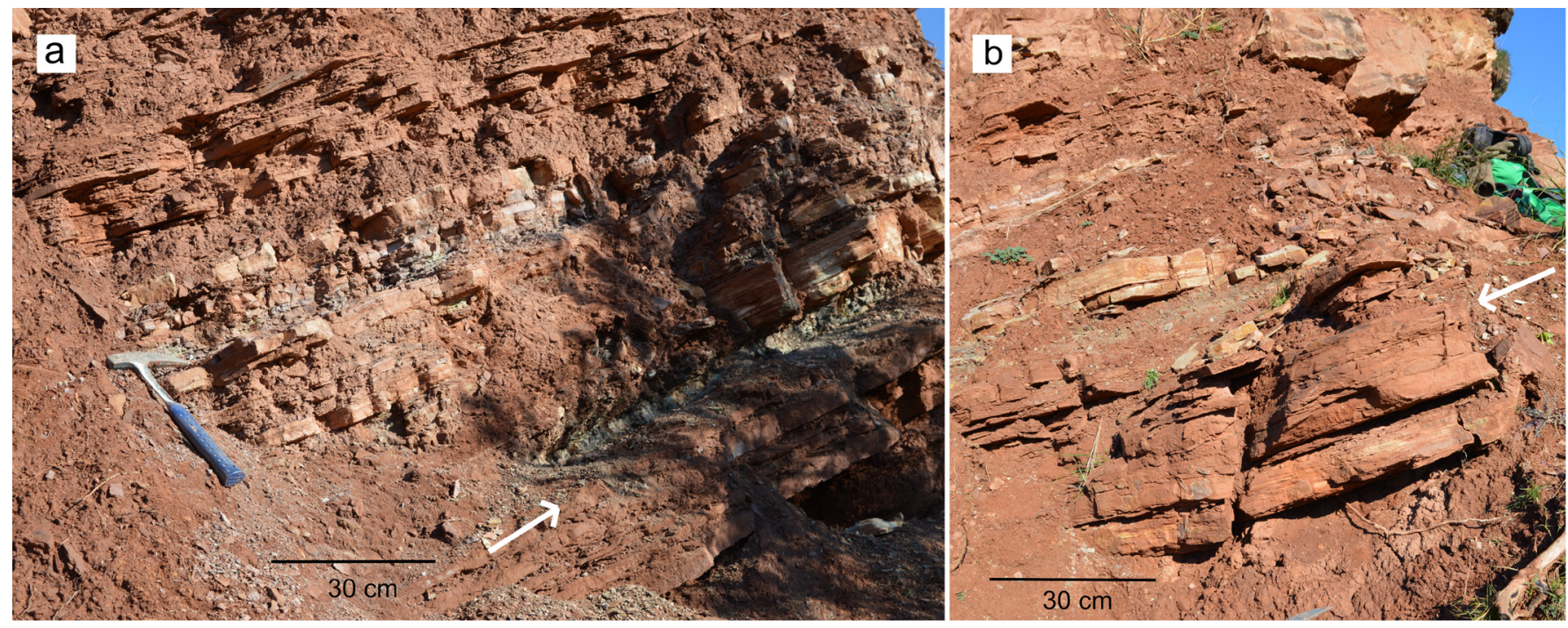

Figure 3. a) General view of the middle Muschelkalk sedimentary succession at Penya Rubí (Vallirana) outcrop. b) Detail of the stratigraphic interval where the sandstone bed preserving the study traceway. The arrows point to the trace-bearing level.

In the Penya Rubí ichnosite a repichnial traceway of a xiphosuran has been recognised (Figs 3-4). These imprints are preserved in a reddish sandstone stratum $(50-60 \mathrm{~cm})$, near to the upper limit between sandstones and a stratified mudstone interval (Figs 2-3). The trace-bearing sandstone presents parallel stratification in its lower part and wave ripples in the topmost part, including the surface where the traceway is impressed. In the overlying strata, in a greyish interval of dolostones and mudstones, tetrapod footprints appear. They are currently under study, preliminarily referred to Rhynchosauroides, Procolophonichnium and Rotodactylus. This interval presents millimetre stratification with alternating thick (greyish) and thin (reddish) laminae building up centimetre sequences. The thick levels are composed of grains coarser than those of the thin levels, and from the bottom to the top, the grain size decreases (fining-upwards sequences).

The overlying interval displays similar stratification than the previous one but it presents reddish colouration; on top of it the first medium-grained sandstone horizons are present. These sandstone beds contain Chirotherium footprints, currently under study, and desiccation cracks at their base. In many of the strata ripples are present. In the finely laminated sequences climbing ripples appear, whereas the coarser and thicker sandstones are characterised by unidirectional ripples.

As a whole, the succession can be interpreted as a coastal area, with bidirectional flows and a certain cyclic sedimentation, as indicated by successive layers of fine grained-sandstones with ripples indicating opposite palaeoflows. Most probably, the succession was deposited in an intertidal area with relatively low energy, as already stated by Ortí et al. (2018; and references therein).

\section{SYSTEMATIC PALAEOICHNOLOGY}

\subsection{Ichnogenus Kouphichnium}

Referred material. The ichnites belong to a relatively regular repetition of symmetrical imprints (IPS110272). This set of imprints is considered to be a traceway preserved in concave epirelief (Figs 4a-e) (see 3-D model available from MorphoBank http://morphobank.org/ permalink/?P3770).

Description. One straight and symmetric traceway, reaching up to $240 \mathrm{~mm}$ long and $26.8 \mathrm{~mm}$ wide. The traceway is composed of five nearly straight parallel rows of ichnites (Figs 4a-4b), which show opposite symmetry. The central row consists of six rectilinear grooves (mean length: $20.6 \mathrm{~mm}$ ). These linear traces are the deepest imprints and present a profound region in the middle of the groove. On both sides, with a symmetric display, numerous smaller prints close to the straight grooves are arranged in two rows in each side. These rows tend to interchange up to four types of imprints (Figs 4c-4d). The first type shows a bifid shape (mean length: $3.3 \mathrm{~mm}$ ) composed of a central point from which two curved scratches emerge. The second type consists of linear scratches, much shorter than the central grooves (mean length: $4.2 \mathrm{~mm}$ ). The shape of these imprints ranges from straight to curved lines. Despite their linear shape, the extreme anterior of the imprint displays a deep and punctuated impression. The third type of imprints shows pointed ichnites (mean length: $2.0 \mathrm{~mm}$ ). Finally, at the edges of the traceway arrow-shaped ichnites make up the fourth type (mean length: $5.4 \mathrm{~mm}$ ). This last imprint type shows the direction of the traceway, starting 

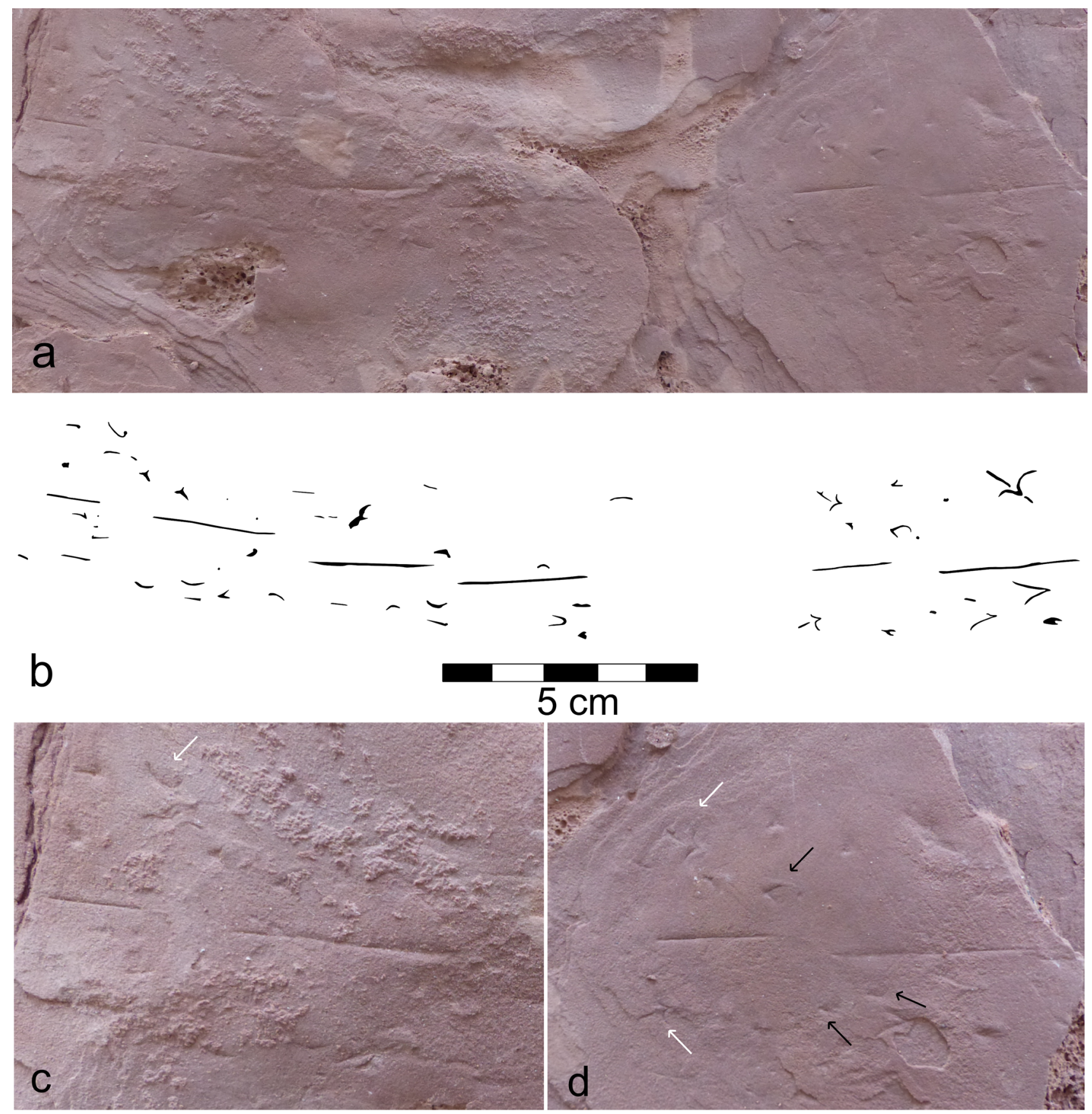

e

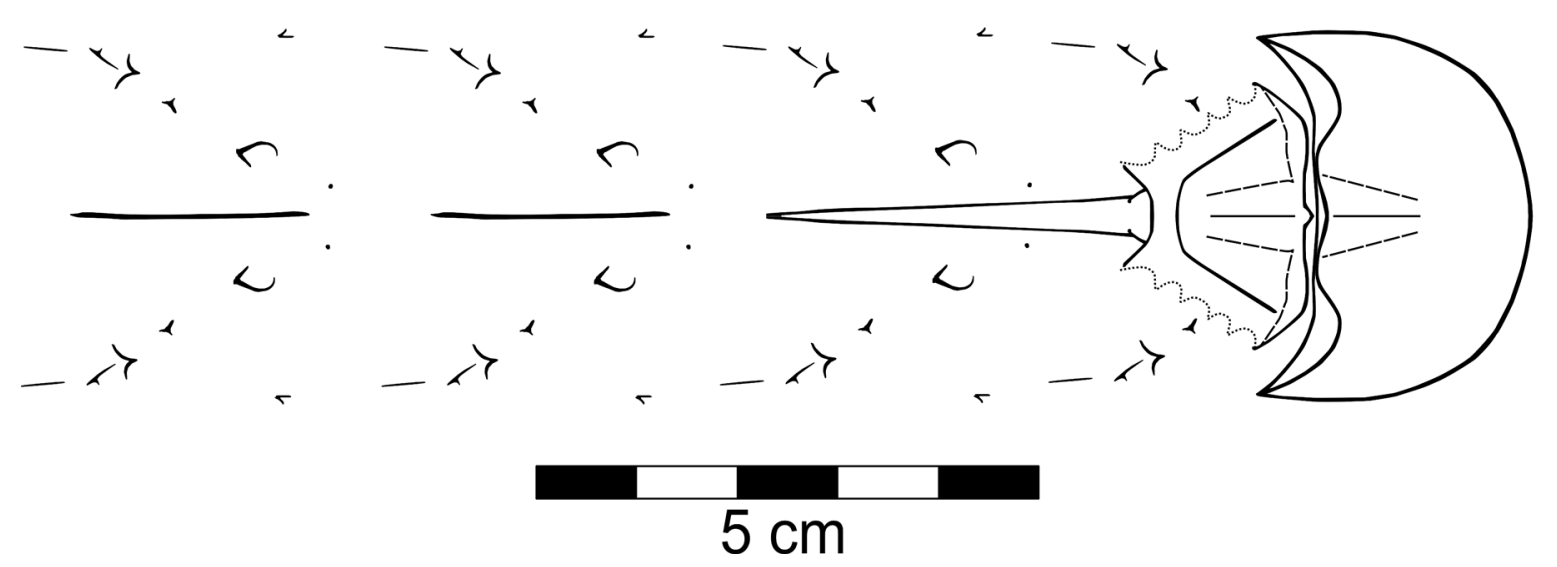


in the middle of the slab and finishing at one of the ends, i.e., the traceway advances towards the bifid and arrowed end of the traces.

The position of each type of imprint is not completely regular along the rows, but it seems to follow a trend. In both lateral rows, the pointed and bifid imprints tend to be in the inner part of the row, while the lineal and arrowshaped frequently appear in the outer side. The arrow shaped and linear traces tend to appear in the posterior part of the telson trace while the bifid and pincer-like imprints are located in the medium part, and the pointed imprints tend to be in the anterior part, near to the telson trace. The inner traces are relatively aligned, outlining a diagonal approaching the central linear groove from the posterior to the anterior. Also, in the upper part of the anterior side is also frequent to find a bifid imprint. The long linear traces are always the central row (Figs 4a-4e).

Discussion. The morphological characters of the imprints reveal that the traceway corresponds to locomotion traces (repichnia) of an arthropod. The presence of a "tail trace", corresponding to the central linear grooves, and the disposition and morphology of the imprints in each side allow assigning the traceway to Kouphichnium. This ichnogenus is interpreted as a repichnion, likely produced by xiphosurans (Caster, 1938; Goldring \& Seilacher, 1971; Seilacher, 2007; Fernández \& Pazos, 2013; Rindsberg \& Martin, 2015; Mujal et al., 2018a; Shu et al., 2018; Shi et al., 2019). The body of the xiphosurans is composed of three main parts: the prosoma (anterior part), the abdomen (central part) and a relatively long telson (posterior part) (Gaillard, 2011) (Fig. 4e). In the abdomen, xiphosurans present six pairs of appendages that contribute to various functions. The first pair of appendages is the chelicere, which end with pincers, being useful for grasping food. The second to fifth pair of appendages is chelate walking legs, all of which display bifid ends (Shi et al., 2019; Shibata \& Varricchio, 2020). The principal function of these appendages is for locomotion. Finally, the sixth pair is known as the pusher legs. They are the strongest appendages and push the animal forward over (commonly soft) substrates (Caster, 1938). This strong heteropody is the cause of the large variability of the resulting traceway (Caster, 1938; Goldring \& Seilacher, 1971; Rindsberg \& Martin, 2015). The anterior five pairs consist in small pincer-like chelipeds, leaving characteristic V-shaped impressions seen in xiphosuran traceways (Shi et al., 2019). On the other hand, the "pusher" legs produce many variable imprints with digitate and flabellar forms (Gaillard, 2011).

As indicated in the description, the position of each type of imprint tends to be regular. The imprints show a descending line from the posterior part of the central row to the anterior part, being the linear and arrow shaped imprints the furthest ones from the telson at the anterior part, whereas the bifid, pincer-like and pointed imprints are the closest at the posterior part. This trend has been represented in an ideal reconstruction of the traceway (Fig. 4e).

Comparing the anatomy of living limulids and the different types of imprints, we can establish a correlation between trace and tracemaker. The central row of straight grooves would be produced by the telson. According to Caster (1938), nowadays xiphosurans would use the telson to raise the posterior part of the prosoma when the rest of the appendix is buried. This behaviour would describe the telson as a key appendix in the locomotion of the xiphosurans. Similarly, Gaillard (2011) suggested such traceways with discontinuous telson impressions as crawling behaviour. Also, according to Caster (1938) and Goldring \& Seilacher (1971), due to the shallow drag of the telson, its impression is only preserved in the superficial laminae of the substrate, hence these imprints usually do not appear as "undertraces" (see also Seilacher, 2007). Otherwise, the two sets of imprints from each side (Figs $4 a-4 b$ ) of the traceway most likely correspond to the walking appendages. The multiple variations of these traces, herein grouped in four types, would represent the locomotion stages of the appendages (Shi et al., 2019).

\section{DISCUSSION}

\subsection{Palaeoecology and palaeoenvironment}

The trace fossils were found in a laminar interval composed by reddish sandstones and mudstones (Fig. 3). The presence of sandstone layers with ripples showing

Figure 4. Kouphichnium isp. (IPS110272) from the middle Muschelkalk facies of Penya Rubí, advancing from left to right in the photos. a) Photo of the whole traceway. b) Interpretative outline of the traceway. c) Detail of the traceway showing the linear ichnites produced by appendages II-V. The arrow points to a curvilinear ichnite. d) Detail of the traceway showing the arrow-shaped imprints produced by appendages VI (white arrows), and pointed, lineal and bifid imprints produced by appendages II-V (black arrow). e) Ideal traceway using Mesolimulus crespelli (redrawn from Vía, 1987; scaled to fit the traceway width) as potential tracemaker. 
opposite palaeoflows, the finely laminated mudstones alternated with sandstones, as well as the presence of climbing ripples, give support to the interpretation of the Penya Rubí outcrop as an intertidal setting, as suggested in other middle Muschelkalk successions (Ortí et al., 2018) and other areas elsewhere (Davis \& Dalrymple, 2012). As explained in the previous section, due to the shallow drag of the telson in xiphosurans, these imprints most commonly do not appear in "undertraces", thus the traceway is most probably preserved in the originally trampled surface.

In addition, the ethology and ecology of extant limulids provides an excellent model for determining the behavioural characteristics and palaeoecology of the ancient xiphosurans (Martin \& Rindsberg, 2007; Seilacher, 2007). Limulids can live in a wide range of environments from freshwater to marginal marine settings (Lamsdell, 2016; Shi et al., 2019). But during their life, limulids inhabit different environmental niches at different ontogenetic stages. Mature individuals mostly live in distal areas of the continental shelf and return to the shore and tidal areas to mate and to lay their eggs in the breeding season (Caster, 1938, 1944; Shuster, 1982; Shi et al., 2019). Juveniles are benthic and live in coastal areas for two years before moving into deeper waters with ageing (Shi et al., 2019). Thus, if it is assumed that the herein studied xiphosuran traceway is the result of similar behaviour, the tracemaker could be a juvenile that lived in the intertidal area or mature specimen that returned to the coast for the breeding season. According to Martin \& Rindsberg (2007) on the studies of recent juvenile limulid traceways, likely producing traces assignable to Nereites, we favour the latter interpretation.

\subsection{Palaeogeographic implications}

In recent years, the fossil record from the Muschelkalk facies of the Catalan Basin and other Iberian basins has been enhanced, particularly due to the discovery of tetrapod footprints (Gand et al., 2010; Fortuny et al., 2011; Mujal et al., 2015, 2018b; Berrocal-Casero et al., 2018). The Penya Rubí ichnosite, where the studied traceway was recovered, is not an exception and several tetrapod footprints have been also recovered here. Otherwise, xiphosuran remains have been historically restricted to the upper Muschelkalk (M3) of Alcover (Catalan Basin, Tarragona province) outcrops (VíaBoada et al., 1977 and references therein). More recently, xiphosuran trace fossils were also discovered in the lower part of the Buntsandstein facies, in non-marine fluvial deposits from the Pyrenean Basin, also stratigraphically and geographically close to tetrapod footprints (Mujal et al., 2017, 2018a).
In the Catalan Basin remains of three limulid taxa have been recovered from the upper Muschelkalk: Tachypleus gadeai (Vía-Boada \& Villalta, 1966) (first described as Heterolimulus gadeai), Tarracolimulus rieki Romero \& Vía-Boada, 1977, and Mesolimulus crespelli Vía, 1987. These species have been described from the quarry of Alcover-Montral (Tarragona, Spain), in Ladinian dolomites. The outcrops of Alcover-Montral (Vía, 1987) are the first areas where Triassic Iberian xiphosuran remains were discovered. Nevertheless, these specimens are slightly younger than the herein reported ichnites.

Outside the Iberian Peninsula, other xiphosuran remains have been recovered in Middle Triassic deposits from peri-Tethys basins. At the German locality of Bernburg, in the Central European Basin, limulid traceways related to shallow marine and intertidal successions have been documented (Diedrich, 2011). A new species of limulid from the Anisian-lower Ladinian of Tunisia has also been described (Błażejowski et al., 2017). This species, Limulitella tejraensis, probably lived in freshwater environments, and would be phylogenetically related with another lower Middle Triassic (Anisian) limulid from France, Limulitella bronni (see Błażejowski et al., 2017).

Beyond Europe and North Africa, some Triassic xiphosuran remains have been discovered. Recently in China, ichnites from the Daye Formation of Guiyang (South China) have been described. Shi et al. (2019) described two different types of traceways referred as Kouphichnium from the Lower Triassic. The palaeoenvironmental conclusions suggest that the tracemakers would inhabit the seafloor at 50-60 m deep, in a complex ichnoassociation with other invertebrates. In North China, Shu et al. (2018) described 44 wellpreserved traceways attributed to Kouphichnium from the upper Permian-Lower Triassic successions. Also, in upper Permian-Lower Triassic terrestrial successions (freshwater settings) from the Central Transantarctic Mountains (Antarctica) several horseshoe crab traceways have been attributed to the ichnospecies Koupichnium natalensis by Hasiotis (2012). Finally, in Madagascar, two specimens of a Lower Triassic limulid were recovered from the Ankitokazo Basin, tentatively determined as the genus Limulitella by Hauschke et al. (2004), and in New South Wales (Australia), the limuloid Dubbolimulus peetae, which would have inhabited freshwater settings during the Middle Triassic, was described (Pickett, 1984).

All these fossil remains suggest that, after the Permian mass extinction, xiphosurans recovered and radiated during the Middle Triassic, with species occupying both marine and, of special note, continental freshwater (Błażejowski et al., 2017; Mujal et al., 2018a). Most of the known Triassic ichnofossil remains of xiphosurans from the present Northern Hemisphere have been described from Europe, with few additional records from North Africa and China. 


\subsection{Size of the tracemaker}

The size of the tracemaker can be inferred from the external width of the traceway, following the formula I $=\mathrm{W} \times 1.5$ (Malz, 1964; Shi et al., 2019), where I is the width of the prosoma of the tracemaker and $\mathrm{W}$ is the external width of the traceway. In the herein reported specimen, the traceway width is $26.8 \mathrm{~mm}$, so the estimated prosoma width is $40.2 \mathrm{~mm}$. Also, using the formula $\mathrm{L}=\mathrm{I}$ $\times 2.12$ (see Shi et al., 2019), the length of the tracemaker (L) can be calculated, being $85.2 \mathrm{~mm}$ for the tracemaker of the studied specimen. The mean $\mathrm{L}$ value obtained in Kouphichnium specimens from the Lower Triassic in Daye Formation (China) is $192.7 \mathrm{~mm}$ (Shi et al., 2019). Mujal et al. (2018a) described Kouphichnium specimens from the upper Lower Triassic of the Catalan Pyrenees of up to $70 \mathrm{~mm}$ wide. In comparison, the size of the tracemaker from Penya Rubí would be among the smallest found in the Triassic ichnofossil record (Table 1). It suggests that the traceway might correspond to a juvenile specimen or a small xiphosuran taxon. However, according to Martin \& Rindsberg (2007), juvenile specimens of xiphosurans might produce traces attributable to Nereites, thus the option of a small-sized xiphosuran taxon as the producer of the studied traceway is preferred.

Table 1. Size comparison. Obtaining the width of the prosoma (I value knowing the width of the traceway, W, using the formula $\mathrm{I}=\mathrm{W} \times 1.5$ ) and the length of the tracemakers ( $\mathrm{L}$ value, using the formula $\mathrm{L}=\mathrm{I} \times$ 2.12) in the xiphosuran traceways from the Lower and Middle Triassic.

\begin{tabular}{llll}
\hline Outcrop & $\begin{array}{l}\text { W value }(\mathbf{m m}) \\
\text { Traceway } \\
\text { width }\end{array}$ & $\begin{array}{l}\text { I value }(\mathbf{m m}) \\
\text { Prosoma } \\
\text { width }\end{array}$ & $\begin{array}{l}\text { L value }(\mathbf{m m}) \\
\text { Tracemaker } \\
\text { length }\end{array}$ \\
\hline $\begin{array}{l}\text { Penya Rubí } \\
\text { this work) }\end{array}$ & 26.8 & 40.2 & 85.2 \\
$\begin{array}{l}\text { Catalan Pyrenees } \\
\text { (Mujal } \text { et al., }\end{array}$ & 70 (maximum) & 105 & 222.6 \\
$\begin{array}{l}\text { 2018a) } \\
\begin{array}{l}\text { Daye Formation } \\
\text { (Shi et al., 2019) }\end{array}\end{array}$ & $46.9-79.2 \mathrm{~mm}$ & 89 (average) & $\begin{array}{l}192.7 \\
\text { (average) }\end{array}$ \\
\hline
\end{tabular}

The Iberian species Mesolimulus crespelli (width measures: $35 \mathrm{~mm}$ for the holotype, and 31 and $53 \mathrm{~mm}$ for the other specimens) presents the most similar size to the studied traceway (Table 2). Also, Tarracolimulus reiki shows a similar size, although it is slightly smaller. Otherwise, Tachypleus gadeai shows the most different size, being larger than $140 \mathrm{~mm}$ wider than the Penya Rubí specimen. Therefore, $M$. crespelli shows the most similar size to the inferred size of the tracemaker of Penya Rubí Kouphichnium traceway, but we cannot ignore that T. reiki had an almost identical size.
Table 2. Width of the Middle Triassic Iberian limulid fossils (all from the upper Muschelkalk of the Catalan Basin) and inferred width of the potential tracemaker for the Penya Rubí traceway. Tachypleus gadeai (measures from Vía-Boada \& Villata, 1966). Tarracolimulus rieki (measures from Romero \& Vía-Boada, 1987). Mesolimulus crespelli (measures from Vía, 1987).

\begin{tabular}{lll}
\hline $\begin{array}{l}\text { Taxon of fossil } \\
\text { limulid }\end{array}$ & $\begin{array}{l}\text { Width measure data } \\
(\mathbf{m m})\end{array}$ & $\begin{array}{l}\text { Mean width } \\
\text { measure }(\mathbf{m m})\end{array}$ \\
\hline Tachypleus gadeai & 181,168 & 174.5 \\
Tarracolimulus rieki & 36.9 & 36.9 \\
$\begin{array}{l}\text { Mesolimulus crespelli } \\
\text { Kouphichnium isp. }\end{array}$ & 35 (holotype), 31, 53 & 39.7 \\
(IPS110272) & 40.2 & 40.2 \\
\hline
\end{tabular}

\section{CONCLUSIONS}

The arthropod traceway recovered from the Penya Rubí ichnosite of the Catalan Basin has been identified as Kouphichnium isp., a locomotion trace fossil (repichnia) attributed to xiphosurans. This is the first invertebrate traceway described from the middle Muschelkalk (Middle Triassic) of the Catalan Basin. The traceway is composed of three parallel rows of imprints, the central one represented by straight grooves (telson impressions) and the lateral rows (two in each side of the telson impression) being composed of straight and pincer-shaped (bifid) imprints (internal row of each side) and pointed and arrow-shaped imprints (external row of each side). The lateral rows evidently correspond to the impressions of the different appendages. According to the general traceway pattern and the arrangement of the different appendages and telson traces, a crawling behaviour was the most probable locomotion style of the tracemaker.

The animal that produced this trace fossil was probably roaming an intertidal area with shallow, quiet water. Considering the size of the imprints, the tracemaker would be a small xiphosuran of $40.2 \mathrm{~mm}$ width, which could possibly be an adult of a small-sized taxon in a breeding season. Comparing the size of the traceway, the Triassic species Mesolimulus crespelli and Tarracolimulus rieki show the most similar size to the theoretical size of the tracemaker of Penya Rubí ichnites, but it is not possible to confidently correlate the traceway with a specific taxon.

\section{ACKNOWLEDGMENTS}

First of all, thanks to the Spanish Society of Palaeontology (SEP), for granting financial aid to carry out this investigation. We are deeply indebted to Dr. Oriol Oms 
(Universitat Autònoma de Barcelona), discoverer of the slab, and also to Dr. Arnau Bolet (University of Bristol and ICP), Manel Méndez (ICP) and Marc Riccetto for helping us during the fieldtrips. Also to Dr. Chabier de Jaime for logistics related to the project. J.F. is supported by the Spanish Agencia Estatal de Investigación and the European Regional Development Fund of the European Union (AEI/ FEDER EU, project CGL2017-82654-P). J.F. is member of the consolidated research group 2017 SGR 86 GRC of the Generalitat de Catalunya. We acknowledge support from the CERCA programme (ICP) from the Generalitat de Catalunya, and the project "Evolució dels ecosistemes durant la transició Paleozoic-Mesozoic a Catalunya" (ref. CLT009/18/00066), financially supported by the Departament de Cultura (Generalitat de Catalunya). We are grateful to Dr. Andrew K. Rindsberg and Dr. Alberto Pérez-López, who reviewed the manuscript and provided valuable and constructive comments that substantially improved a previous version of this work.

\section{REFERENCES}

Benton, M.J. \& Newell, A.J. 2014. Impacts of global warming on Permo-Triassic terrestrial ecosystems. Gondwana Research, 25, 1308-1337; doi: 10.1016/j. gr.2012.12.010.

Berrocal-Casero, M., Arribas, M. \& Moratalla, J.J. 2018. Didactic and divulgative resources of the Middle Triassic vertebrate Tracksite of Los Arroturos (Province of Guadalajara, Spain). Geoheritage, 10, 375-384; doi: 10.1007/s12371-017-0244-1.

Bicknell, R.D.C., Brougham, T., Charbonnier, S., Sautereau, F., Hitij, T. \& Campione, N. 2019. On the appendicular anatomy of the xiphosurid Tachypleus syriacus and the evolution of fossil horseshoe crab appendages. The Science of Nature, 106, 38; doi: 10.1007/s00114-0191629-6.

Błażejowski, B., Niedźwiedzki, G., Boukhalf, K. \& Soussi, M. 2017. Limulitella tejraensis, a new species of limulid (Chelicerata, Xiphosura) from the Middle Triassic of southern Tunisia (Saharan Platform). Journal of Paleontology, 91, 960-967; doi: 10.1017/jpa.2017.29.

Calvet, F. \& Marzo, M. 1994. El Triásico de las Cordilleras Costero Catalanas: Estratigrafía, Sedimentología y Análisis Secuencial. Cuaderno de Excursión. III Coloquio de Estratigrafía y Paleoestratigrafía del Pérmico y Triásico de España. Field Guide. 1-53.

Calvet, F., Tucker, M.E. \& Henton, J.M. 1990. Middle Triassic carbonate ramp systems in the Catalan Basin, northeast Spain: facies, systems tracts, sequences and controls. Special Publications International Assotiation of Sedimentology, 9, 79-108.

Caster, K.E. 1938. A restudy of the Tracks of Paramphibius. Journal of Paleontology, 12, 3-60.
Caster, K.E. 1944. Limuloid trails from the upper Triassic (Chinle) of the Petrified Forest National Monument, Arizona. American Journal of Science, 242, 74-84.

Davis, R.A., Jr. \& Dalrymple, R.W. (eds.) 2012. Principles of Tidal Sedimentology. Springer, London.

Diedrich, C.G. 2011. Middle Triassic horseshoe crab reproduction areas on intertidal flats of Europe with evidence of predation by archosaurs. Biological Journal of the Linnean Society, 103, 76-105; doi: 10.1111/J.10958312.2011.01635.X.

Escudero-Mozo, M.J., Márquez-Aliaga, A., Goy, A., MartínChivelet, A., López-Gómez, J., Márquez, L., Arche, A., Plasencia, P., Pla, C., Marzo, M. \& Sánchez-Fernández, D. 2015. Middle Triassic carbonate platforms in eastern Iberia: Evolution of their fauna and palaeogeographic significance in the Western Tethys. Palaeogeography, Palaeoclimatology, Palaeoecology, 417, 236-260; doi: 10.1016/j.palaeo.2014.10.041.

Falkingham, P.L. 2012. Acquisition of high resolution 3D models using free, open-source, photogrammetric software. Paleontologia Electronica, 15, 1-15; doi: 10.26879/264.

Fernández, D.E. \& Pazos, P.J. 2013. Xiphosurid trackways in a Lower Cretaceous tidal flat in Patagonia: Palaeoecological implications and the involvement of microbial mats in tracefossil preservation. Palaeogeography, Palaeoclimatology, Palaeoecology, 375, 16-29; doi: 10.1016/j.palaeo.2013.02.008.

Fortuny, J., Bolet, A., Sellés, A.G., Cartanyà, J. \& Galobart, À. 2011. New insights on the Permian and Triassic vertebrates from the Iberian Peninsula with emphasis on the Pyrenean and Catalonian basins. Journal of Iberian Geology, 37, 65-86; doi: 10.5209/rev_JIGE.2011.v37. n1.5.

Franz, M., Kaiser, S.I., Fischer, J., Heunisch, C., Kustatscher, E., Luppold, F.W., Berner, U. \& Röhling, H.-G. 2015. Eustatic and climatic control on the Upper Muschelkalk Sea (late Anisian/Ladinian) in the Central European Basin. Global and Planetary Change, 135, 1-27; doi: 10.1016/j.gloplacha.2015.09.014.

Gand, G., De La Horra, R., Galán-Abellán, B., LópezGómez, J., Barrenechea, J.F., Arche, A. \& Benito, I. 2010. New ichnites from the Middle Triassic of the Iberian Ranges (Spain) paleoenvironmental and paleogeographical implications. Historical Biology, 22, 40-56; doi: 10.1080/08912961003644096.

Gaillard, C. 2011. A giant limulid trackway (Kouphichnium lithographicum) from the lithographic limestones of Cerin (late Kimmeridgian, France): Ethological and environmental implications. Swiss Journal of Geosciences, 104, 57-72; doi: 10.1007/s00015-0100032-2.

Galán-Abellán, B., López-Gómez, J., Barrenecha, J.F., Marzo, M., De la Horra, R. \& Arche, A. 2013. The beginning of the Buntsandstein cycle (Early-Middle Triassic) in the Catalan Ranges, NE Spain: Sedimentary and palaegeographic implications. Sedimentary Geology, 296, 86-102; doi: 10.1016/j.sedgeo.2013.08.006. 
Goldring, R. \& Seilacher, A. 1971. Limulid undertracks and their sedimentological implications. Neues Jahrbuch für Geologie und Paläontologie Abhandlungen, 137, 422-442.

Hasiotis, S.T. 2012. Horseshoe crabs lived in Permo-Triassic Antarctic freshwater rivers and lakes: Trace fossil evidence from the Buckley and Fremouw Formations Beardmore Glacier Area, Central Transantarctic Mountains (CTAM), Antarctica. Geological Society of America, Abstracts with Programs, 44, 500.

Hauschke, N., Wilde, V. \& Brauckmann, C. 2004. Triassic limulids from Madagascar missing links in the distribution of Mesozoic Limulacea. Neues Jahrbuch für Geologie und Paläontologie, 87-94; doi: 10.1127/njgpm/2004/2004/87.

Kin, A. \& Błażejowski, B. 2014. The horseshoe crab of the genus Limulus: Living fossil or stabilomorph? PLoS ONE, 9, e108036; doi: 10.1371/journal.pone.0108036.

Lamsdell, J.C. 2016. Horseshoe crab phylogeny and independent colonizations of fresh water: Ecological invasion as a driver for morphological innovation. Palaeontology, 59, 181-194; doi: 10.1111/pala.12220.

Latreille, P.A. 1802. Histoire Naturelle, Générale et Particulière des Crustacés et des Insectes. Paris, de l'Imprierie de F. Dufart.

Mallison, H. \& Wings, O. 2014. Photogrammetry in paleontology, a practical guide. Journal of Paleontological Techniques, 12, 1-31.

Malz, H. 1964. Kouphichnium walchi, die Geschichte einer Fährte und ihres Tieres: Natur und Museum, 94, 81-97.

Marcé-Nogué, J., Fortuny, J., Gil, L. \& Sánchez, M. 2015. Improving mesh generation in finite element analysis for functional morphology approaches. Spanish Journal of Palaeontology, 30, 117-132.

Márquez-Aliaga, A., Valenzuela-Rios, J.I., Calvet, F. \& Budurov, K. 2000. Middle Triassic conodonts from northeastern Spain; biostratigraphic implications. Terra Nova, 12, 77-83; doi: 10.1111/j.1365-3121.2000.00273.x.

Martin, A.J. \& Rindsberg, A.K. 2007. Arthropod tracemakers of Nereites? -Neoichnological observations of juvenile limulids and their paleoichnological applications. In: Trace Fossils: Concepts, Problems, Prospects (ed. Miller, W. III). Elsevier. 478-491.

Moore, R.A., McKenzie, S.C. \& Lieberman, B.S. 2007. A Carboniferous synxiphosurine (Xiphosura) from the Bear Gulch Limestone, Montana, USA. Palaeontology, 50, 1013-1019; doi: 10.1111/j.1475-4983.2007.00685.x.

Mujal, E., Fortuny, J., Rodríguez-Salgado, P., Diviu, M., Oms, O. \& Galobart, À. 2015. First footprints occurrence from the Muschelkalk detritical unit of the Catalan Basin: 3D analyses and palaeoichnological implications. Spanish Journal of Palaentology, 30, 97-107.

Mujal, E., Fortuny, J., Bolet, A., Oms, O. \& López, J.Á. 2017. An archosauromorph dominated ichnoasssemblage in fluvial settings from the late Early Triassic of the Catalan Pyrenees. PLoS ONE, 12, e0174693; doi: 10.1371/ journal.pone.0174693.

Mujal, E., Belaústegui, Z., Fortuny, J., Bolet, A., Oms, O. \& López, J.Á. 2018a. Ichnological evidence of a horseshoe crab hot-spot in the Early Triassic Buntsandstein continental deposits from the Catalan Pyrenees (NE Iberian Peninsula). Journal of Iberian Geology, 44, 139153; doi: 10.1007/s41513-017-0026-2.

Mujal, E., Iglesias, G., Oms, O., Fortuny, J., Bolet, A. \& Méndez, J.M. 2018b. Rhynchosauroides footprint variability in a Muschelkalk detrital interval late Anisian-middle Ladinian) from the Catalan Basin (NE Iberian Peninsula). Ichnos, 25, 150-161; doi: 10.1080/10420940.2017.1337571.

Mujal, E., Marchetti, L., Schoch, R.R. \& Fortuny, J. 2020. Upper Paleozoic to Lower Mesozoic tetrapod ichnology revisited: Photogrammetry and relative depth pattern inferences on functional prevalence of autopodia. Frontiers in Earth Science, 8, 248; doi: 10.3389/feart.2020.00248.

Ortí, F., Salvany, J.M., Rosell, L., Castelltort, X., Inglès, M. \& Playà, E. 2018. Middle Triassic evaporite sedimentation in the Catalan Basin: implications for the paleogeographic evolution in the NE Iberian Platform. Sedimentary Geology, 374, 158-178; doi: 10.1016/j.sedgeo.2018.07.005.

Pickett, J.W. 1984. A new freshwater limuloid from the Middle Triassic of New South Wales. Palaeontology, 27, 609-621.

Ramón, X. \& Calvet, F. 1987. Estratigrafía y sedimentología del Muschelkalk inferior del dominio Monserrat-Llobregat (Catalanides). Estudios Geológicos, 43, 471-487.

Rindsberg, A.K. \& Martin, A.J. 2015. Caster's Plasters: Neoichnological Experiments by Kenneth Caster on Limulids in 1937. In: ICHNOLOGY: Papers from ICHNIA III: Geological Association of Canada, Miscellaneous Publications (eds McIlroy, D.). 197-210.

Romero, A. \& Vía-Boada, L. 1977. Tarracolimulus rieki, nov. gen., nov. sp., nuevo limúlido del Triásico de MontralAlcover. Cuadernos de Geología Ibérica, 4, 239-246.

Rudkin, D.M., Young, G.A. \& Nowlan, G.S. 2008. The oldest horseshoe crab: A new xiphosurid from Late Ordovician Konservat-Lagerstätten deposits, Manitoba. Canada. Palaeontology, 51, 1-9; doi: 10.1111/j.14754983.2007.00746.x.

Seilacher, A. 2007. Trace Fossil Analysis. Berlin, Springer. Shen, J., Schoepfer, S.D., Feng, Q., Zhou, L., Yu, J., Song, H., Wei, H. \& Algeo, T.J. 2015. Marine productivity changes during the end-Permian crisis and Early Triassic recovery. Earth-Science Reviews, 149, 136-162; doi: 10.1016/j. earscirev.2014.11.002.

Shi, G., Woods, A.D., Yu, M.-Y., Li, X.-W., Wei, H.-Y. \& Qiao, D. 2019. Lower Triassic limulid trackways (Kouphichnium) from the southwestern margin of the Yangtze carbonate platform: paleoenvironmental and paleoecological implications. Palaios, 34, 229-243; doi: 10.2110/palo.2018.081.

Shibata, M. \& Varricchio, D.J. 2020. Horseshoe crab trace fossils from the Upper Cretaceous Two Medicine Formation of Montana, USA, and a brief review of the xiphosurid ichnological record. Journal of Paleontology, 1-19; doi: 10.1017/jpa.2020.16.

Shu, W., Tong, J., Tian, L., Benton, M.J., Chu, D., Yu, J. \& Guo, W. 2018. Limuloid trackways from Permian-Triassic 
continental successions of North China. Palaeogeography, Palaeoclimatology, Palaeoecology, 508, 71-90; doi: 10.1016/j.palaeo.2018.07.022.

Shuster, C.N., Jr. 1982. A pictorial review of the natural history and ecology of the horseshoe crab Limulus Polyphemus, with reference to other Limulidae. In: Physiology and Biology of Hrseshoe Crabs. Studies on Normal and Environmentally Stressed Animals (eds Bonaventura, J., Bonaventura, C. \& Tesh, S.). New York. Alan R. Liss, Inc, 1-55.

Solé de Porta, N., Calvet, F. \& Torrento, L. 1987. Análisis palinológico del Triásico de los Catalanides (NE España). Cuadernos de Geología Ibérica, 11, 237-254.
Vía, L. 1987. Artrópodos fósiles triásicos de Alcover-Montral. II. Limúlidos. Cuadernos de Geología Ibérica, 11, 281-282.

Vía-Boada, L. \& Villata, J.F. 1966. Heterolimulus gadeai nov. gen., nov. sp., representante de una nueva familia de LIMULACEA, en el Triásico español. Acta geológica Hispánica, 1, 9-11.

Vía-Boada, L., Villalta, J.F. \& Cerdá, M.E. 1977. Paleontología y paleoecología de los yacimientos fosilíferos del Muschelkalk Superior entre Alcover y Mont-Ral (Montañas de Prades, Provincia de Tarragona). Cuadernos de Geología Ibérica, 4, 247-256.

Virgili, C., Sopeña, A., Ramos, A. \& Hernando, S. 1977. Problemas de la cronoestratigrafía del Trías en España. Cuadernos de Geología Ibérica, 4, 57-87. 